Policy Research Working Paper 2902

\title{
Aid, Policy, and Growth in Post-Conflict Societies
}

Paul Collier

Anke Hoeffler 
Policy Research Working Paper 2902

\section{Abstract}

Countries emerging from civil war attract both aid and policy advice. This paper provides the first systematic empirical analysis of aid and policy reform in the postconflict growth process. It is based on a comprehensive data set of large civil wars and covers 27 countries that were in their first decade of post-conflict economic recovery during the 1990s.

Collier and Hoeffler first investigate whether the absorptive capacity for aid is systematically different in post-conflict countries. They find that during the first three post-conflict years, absorptive capacity is no greater than normal, but that in the rest of the first decade it is approximately double its normal level. So ideally, aid should phase in during the decade. Historically, aid has not, on average, been higher in post-conflict societies, and it has tended to taper out over the course of the decade.

The authors then investigate whether the contribution of policy to growth is systematically different in postconflict countries, and in particular, whether particular components of policy are differentially important. For this they use the World Bank policy rating database. The authors find that growth is more sensitive to policy in post-conflict societies. Comparing the efficacy of different policies, they find that social policies are differentially important relative to macroeconomic policies. However, historically, this does not appear to have been how policy reform has been prioritized in post-conflict societies.

This paper-a product of the Development Research Group-is part of a larger effort in the group to study the economics of conflict. Copies of the paper are available free from the World Bank, $1818 \mathrm{H}$ Street NW, Washington, DC 20433. Please contact Audrey Kitson-Walters, room MC3-527, telephone 202-473-3712, fax 202-522-1150, email address akitsonwalters@worldbank.org. Policy Research Working Papers are also posted on the Web at http://econ.worldbank.org. Paul Collier may be contacted at pcollier@worldbank.org. October 2002. (24 pages)

The Policy Research Working Paper Series disseminates the findings of work in progress to encourage the exchange of ideas about development issues. An objective of the series is to get the findings out quickly, even if the presentations are less than fully polished. The papers carry the names of the authors and should be cited accordingly. The findings, interpretations, and conclusions expressed in this paper are entirely those of the authors. They do not necessarily represent the view of the World Bank, its Executive Directors, or the countries they represent. 


\section{Aid, Policy and Growth in Post-Conflict Societies}

Paul Collier and Anke Hoeffler 



\section{Introduction}

In January 2002 the international donor community pledged $\$ 4.5 \mathrm{bn}$ in aid to Afghanistan for post-conflict reconstruction. This follows similarly substantial donor responses in East Timor and Bosnia. By contrast, donor responses to the end of some other conflicts have been modest, with the international financial institutions sometimes constrained by the problem of arrears of debt, precluding renewed lending. Evidently, the enormous variation in response is because post-conflict situations are sometimes highly politicized. However, since the needs of post-conflict situations compete for the same pool of resources devoted to aid for development, it is useful to benchmark the efficacy of aid in post-conflict situations relative to development assistance more generally.

The general effectiveness of aid in reducing poverty can be benchmarked using the analysis of Collier and Dollar (2002). They first estimate a relationship between aid, policy and growth. They find that aid is subject to diminishing returns, but that absorptive capacity is dependent upon the level of policy and institutions as measured by the World Bank's annual rating, the Country Policy and Institutional Assessment (CPIA). They then estimate a relationship between growth and poverty reduction: the reduction in poverty depends upon the extent of poverty and upon the distribution of income. From these relationships they estimate a 'poverty-efficient' allocation of aid between countries, this being the allocation that would maximize the reduction in poverty for a given overall aid budget. The World Bank's allocation rules for IDA, its concessional lending to lowincome countries, now reflect this framework, as increasingly does the allocation of bilateral aid. However, post-conflict situations are not explicitly considered in the Collier-Dollar analysis: 'poverty-efficient' aid for post-conflict countries makes no allowance for their special circumstances other than what is already reflected in the CPIA rating. The economic circumstances of post-conflict societies are distinctive in several respects (Collier, 1999). Typically, opportunities for recovery enable a phase when growth is supra-normal. The need to restore infrastructure, juxtaposed against the collapse of revenue, tend to make aid unusually productive. However, offsetting this, during civil war the normal incentive to maintain a reputation for honesty is often disrupted, switching the society into a persistent high-corruption equilibrium (Tirole, 1992). This, together with the weakening of civil administration, can make aid less effective. Hence, a priori, aid might be more or less productive in post-conflict societies.

Reflecting the presumed need for differential treatment, the IDA allocation formula has recently been revised to allow post-conflict countries to receive additional temporary resources. However, at present this is based on judgment rather than quantitative analysis. The primary purpose of this paper is to bring post-conflict situations explicitly into the poverty-efficiency framework of aid allocation. The resulting benchmarks are all the more necessary given the highly politicized nature of aid allocation in post-conflict situations. Of course, aid in post-conflict situations has legitimate objectives other than poverty reduction. There is a considerable risk that conflict will resume and aid might directly reduce this risk beyond any effects via growth and poverty reduction. However, a benchmark in terms of the objective of poverty reduction can at least provide guidance to 
donors as to the lower bound for appropriate response. Since aid tends, through its growth effects, to reduce the risk of conflict (Collier and Hoeffler, 2002), the aid allocation warranted on the criterion of poverty reduction will also contribute to peace-building.

A second purpose of the paper is to investigate whether and how priorities for the reform of policies, governance and institutions might differ in post-conflict societies from those in other developing countries. At the most obvious level, priorities might differ because some problems are atypically severe. For example, if inflation were to be atypically high in post-conflict situations then improved macroeconomic management would be atypically important. Less obviously, some reforms might be atypically important not because the attained level of performance is worse than in other societies, but because the economy is atypically sensitive to them. We use a new data set on disaggregated ratings of different aspects of policy, governance and institutions to test for differential priorities.

In Section 2 we focus upon the pattern of post-conflict economic recovery. We find that there is typically a brief phase of supra-normal growth. In Section 3 we investigate whether aid affects growth differently in post-conflict situations, and from this estimate the volume of aid that is appropriate in post-conflict situations on the criterion of povertyreduction. We show that historically, the actual donor response to post-conflict situations has not been poverty-efficient. In Section 4 we turn to policy, investigating how priorities between broad categories of policy - macroeconomic, structural, social and governance should be distinctive in post-conflict situations. We find that historically there has been no tendency of policies to reflect these priorities.

\section{The pattern of post-conflict recovery}

We first investigate whether there are exogenous forces for economic recovery from conflict, in the sense that growth is more rapid during the post-conflict phase controlling for policies and for aid inflows.

For the growth relationship we rely upon the analysis and database used in the CollierDollar growth regression (Collier and Dollar, 2002). This analyzes the per capita growth rate over each four-year period from 1974 to 1997 for 62 countries. We introduce conflicts into this analysis using the database of Collier and Hoeffler (2002a), which provides a comprehensive listing and dating of civil wars for 1960-99. They use a definition of civil war that is conventional in the academic literature: namely, an internal conflict between a government and an identifiable rebel organization that results in at least 1,000 combat-related deaths, of which at least $5 \%$ must be incurred on each side. Most of these 73 wars did not end within the period analyzed by Collier and Dollar, or, due to data limitations, were in countries other than the 64 included in their analysis. Table Al lists all those post-civil war situations in the Collier and Hoeffler data set that fall within the 1974-97 period analyzed by Collier and Dollar, and shows which of them have sufficient data to be included in the present analysis. 
The Collier-Dollar regression analyzes growth averaged over four-year periods, thereby abstracting from short-term fluctuations, generating 344 growth episodes. We wish to analyze the after-effects of conflict for around the first decade of peace. We therefore consider three episodes: that in which the conflict ends, which we refer to as peace onset, and the two following periods. When these three episodes are pooled we have 34 observations for which we have complete data. When we look at individual episodes for some purposes we increase the number of observations by dropping some dataconstraining variables. At the maximum our analysis uses 48 post-conflict episodes.

The first column of. Table 1 reproduces the core Collier-Dollar regression'. The regression captures the effects of policy, institutions, governance and aid, while controlling for the initial level of income, the region, and the time period. Policy and institutions, as measured by the CPIA, and governance, as measured by the ICRGE, both directly contribute to growth. Aid is subject to diminishing returns, but the absorptive capacity for aid is dependent upon policy and institutions - the better are policy and institutions, the more aid can be absorbed before the marginal contribution of aid to growth falls to zero.

In the second column of Table 1 we introduce a dummy variable for countries that are in any of the three post-conflict episodes. Thus, if a conflict ended in 1975, the post-conflict dummy variable would take the value of unity for each of the growth episodes 1974-77, 1978-81, and 1982-85. Thereafter, the dummy would revert to zero, the country being treated as 'post-post-conflict'. The dummy is significant: controlling for policy, institutions, governance and aid, post-conflict countries on average grew $1.13 \%$ more rapidly than other countries. Since the growth rate for the average country in the whole sample was only $1.65 \%$, this increment is substantial.

We next investigate whether this additional growth has any temporal pattern. For example, it might be concentrated in the initial post-conflict years as the economy bounces back. Alternatively, following Olson's classic analysis of how episodes of conflict can break the gridlock of pressure groups, rapid growth might be sustained over many years. We first focus on the peace-onset episode. This is made up of two distinct sub-periods, that during which the war is being fought, and that during which peace has been re-established. The net effect on growth during the episode is therefore the combination of a war-effect that is likely to be negative, and a peace-onset effect that may be positive. Hence, in column 3 we introduce two additional variables. The first measures the number of war months during each episode ('warmonths'), and the second measures the number of months of peace during the peace-onset episode ('peace-onset'). The latter variable tests whether growth is distinctive following the onset of peace. Although these variables have the expected signs, neither is significant (nor are they significantly different from each other). Evidently the adverse effects of war on growth are largely captured by the deterioration in the CPIA, and there is no significant bounce-

\footnotetext{
' Five observations were mis-coded in the original regression, missing CPIA values being coded as zeros. This is corrected in the present regression which accounts for the slight differences with the published version.
} 
back in the early post-conflict years other than through effects captured in the improvement in the CPIA.

In column 4 we focus on the second post-conflict episode, this being the first full period of peace. Here, we use a dummy variable to test for whether growth during this period is distinctive. To maintain comparability with the Collier-Dollar results we revert to the regression of column 2, dropping the two insignificant variables added in column 3 . The dummy variable is significant and substantial - during this period the growth rate is nearly two percentage points above normal. In column 5 we replace this dummy with one for the third post-conflict episode. Both statistical and economic significance are now reduced: supra-normal growth is $1.2 \%$.

These results suggest that post-conflict deviations from the normal growth relationship follow an inverted-U pattern over the first post-conflict decade. However, since the dating of the four-year growth episodes in the Collier-Dollar analysis is exogenous, the above approach lacks precision: the first post-conflict period may contain anything from zero to 47 months of peace, and although the second post-conflict period will always contain 48 months of peace, these may range from starting in the second month of peace, through to starting in the $48^{\text {th }}$ month. To try to get more precision as to when in the postconflict period growth is supra-normal, in Table 2 we therefore replace the period dummies with eight variables defined in terms of the time that has lapsed since the end of the conflict. Thus, 'Year 1' measures the number of months in the growth episode that meet the criterion of being during the first 12 months of the end of the war. Similarly, 'Year 2' measures the number of months during the growth episode that meet the criterion of being between the $13^{\text {th }}$ and the $24^{\text {th }}$ month after the end of the war. The variables between them span the first eight years post-conflict. Given these definitions, the values of the variables are logically interdependent. For example, if 'Year 4' takes the value of 12, then 'Year 8' must take the value of zero, while 'Year 5' is highly likely to be non-zero. This interdependence makes it inappropriate to enter the variables into the regression collectively, and in columns 1-8 we enter them individually. Even so the interpretation of the variables must be treated with caution: for example, the coefficient on 'Year 4' will capture not only the effect of the fourth year of peace, but also the effects of those years for which the other year variables are likely to be non-zero. With these caveats, the variables representing the first four years of peace are insignificant (with the fourth being borderline), the variables representing the fifth through the seventh year are all significant, with the size of the coefficient rising through to the sixth year and then declining in the seventh. The variable for the eighth year reverts to insignificance. This suggests that the peak phase for supra-normal growth is between the fourth or fifth and seventh years of post-conflict peace. We test this further by replacing the year variables by two dummy variables. The first takes the value of unity if the growth episode contains any months that fall within the first three years of peace (that is, if any of the first three 'Year' variables are non-zero). The second dummy variable takes the value of unity if and of the 'Year' variables 4 through 7 are non-zero. The results are shown in column 9. The first variable is insignificant, whereas the second variable is significant and substantial - the supra-normal growth rate is $1.5 \%$. 
To summarize, we have investigated the time-profile of post-conflict growth through two approaches. The first defines three four-year episodes: peace onset and the two subsequent periods. The second allows us to date the onset of peace more precisely but encounters some difficulties of interpretation. Both approaches reveal an inverted-U pattern. On the first approach supra-normal growth peaks in the second period. This period will range from being virtually the first four years of peace to virtually the second four years of peace. The second approach dates the peak growth phase more precisely as being from the fourth to the seventh year of peace. Such a pattern of recovery is not $a$ priori surprising. In the immediate aftermath of conflict there are probably many uncertainties, and basic functions of government have yet to be re-established. If peace is maintained there is then a phase of catch-up, but this peters out and the economy reverts to its long-run growth rate.

\section{Aid during recovery}

Thus, for a relatively short phase post-conflict, growth is supra-normal. We now investigate the contribution of aid, especially during this phase. The Collier-Dollar analysis of growth found that growth is augmented both by aid and by policy, supporting, with a broader measure of policy, the prior analysis of Burnside and Dollar (2001). The supra-normal growth phase could be due to a changed relationship between aid, policy and growth: most notably for our present purposes it could be because aid is atypically effective. However, it could also be because of some effect exogenous to both aid and policy: for example, peace simply enables normal economic activity to be resumed so that the economy bounces back.

We decompose supra-normal growth by introducing terms that interact the aid and policy variables with the post-conflict dummies for each of the three episodes. In the baseline Collier-Dollar model there are three such potential interactions - with aid, with policy, and with the policy-aid interaction. ${ }^{2}$ We initially focus on the first full four-year period of peace, since this is the period during which growth is supra-normal. We introduce all three interaction terms and proceed with stepwise reduction to those that are significant. This is shown in the first four columns of Table 3. The stepwise reduction eliminates the direct effect of post-conflict on growth as insignificant. Supra-normal growth is not due to automatic 'bounce-back'. The final regression (column 4) retains only one route by which post-conflict effects growth, namely the interaction between the post-conflict dummy and the aid-policy interaction variable. This new double interaction term is highly significant both in the statistical sense and in the economic sense.

The coefficient on the new term has important implications for aid absorption postconflict. The Collier-Dollar analysis finds that aid is subject to diminishing returns, so

\footnotetext{
${ }^{2}$ Potentially, aid can enter the regression twice, both directly and squared. The squared term is necessary to capture diminishing returns, but, given the inclusion of the aid-policy interaction term, whether a separate term for the direct effect of aid is needed is entirely an empirical matter. Collier and Dollar (2002) show that when such a term is included it is insignificant and so it is dropped from their core regression.
} 
that at some point - the saturation point - aid becomes ineffective in raising growth. The saturation point depends upon policy - the better is policy the greater the amount of aid that can be productively absorbed. The growth regression takes the form:

$$
g=a+b A P-c A^{2}
$$

where:

$\mathrm{g}=$ the growth rate

$A=$ aid (as a share of GDP)

$\mathrm{P}=$ policy and institutions (as measured by the CPIA).

The contribution of aid to growth is thus:

$$
\mathrm{dg} / \mathrm{dA}=\mathrm{bP}-2 \mathrm{cA}
$$

so that the saturation point, $A^{s}$, is defined by:

$$
A^{s}=(b / 2 c) P
$$

In the baseline Collier-Dollar regression reported in Table 1, column 2, the coefficients imply that the saturation point is 2.5 times the CPIA score. A typical CPIA score is around three, so that the result implies that normal absorptive capacity for aid has a limit of around 7.5\% of GDP. It is important to note that in the Collier-Dollar analysis aid is measured at purchasing power parity prices. With the more conventional measure of aid at prevailing exchange rates, this would translate into around $20 \%$ of GDP.

The results of Table 3, column 4, decompose the saturation point into that which applies in the first full period of post-conflict peace, and all other observations. The introduction of the post-conflict term slightly reduces the estimate of the saturation point in normal circumstances to 2.27 times the CPIA. However, the estimate of the saturation point during post-conflict is dramatically larger, at 5.59 times the CPIA. Thus, conditional upon policy and institutions, post-conflict countries have more than double the absorptive capacity for aid of that in more normal circumstances.

It does not necessarily follow from this that post-conflict countries should get more aid that other countries with similar levels of poverty. Allowance must be made for the unsurprising fact that policies and institutions tend to be less satisfactory in post-conflict situations. Hence, the greater absorptive capacity conditional upon policy, is qualitatively offset by worse policy: To quantify this, for the 1990s we compare the average CPIA score for all countries with that for those countries in their first full period of post-conflict peace. The former is 3.00 and the latter is 2.88 . The typical country in its first full fouryear period of post-conflict peace thus has a saturation point around 2.36 times that for the typical country in other circumstances. ${ }^{3}$

\footnotetext{
${ }^{3}(2.88 / 3.00) \cdot(5.59 / 2.27)=2.36$
} 
To summarize, during the first full period of post-conflict, the typical country experiences a temporary growth spurt of around two percentage points per year in excess of normal growth. This growth spurt is largely, or entirely, dependent upon aid: for given policies aid is more than twice as productive in post-conflict circumstances, and so at normal levels of aid, growth is higher. In the absence of aid there would be no growth spurt.

We next consider whether these effects of aid are distinct to the first full period of postconflict peace. To investigate the effects of peace onset we use the 'peace-onset' variable analogously to our previous use of the dummy for the first full episode of peace, again using a stepwise process of reduction. The results, reported in Table 3 columns 5-8, show that there is no significant growth effect through any route during the peace onset period. Recall that there is also no supra-normal growth in this period. To investigate the effects during the second full peace episode is problematic: there are only seven countries in the Collier-Dollar sample that have completed this peace period and such a sample is evidently too small for meaningful analysis. Recall that there are indications that after the first full peace period the supra-normal growth effect starts to fade. Presumably, postconflict countries gradually revert to the normal growth relationships.

To summarize, the end of a civil war creates a temporary phase during which aid is particularly effective in the growth process. Our results suggest that during the first full peace period the absorptive capacity for aid is around double its normal level. As with aid in more normal circumstances, absorptive capacity depends upon policy, but, conditional upon policy, aid is considerably more effective. Although policy is worse in post-conflict societies than in most other societies, this is insufficient to offset the greater absorptive capacity, so that post-conflict societies constitute an important exception to the proposition that for given levels of poverty, aid should be lower in societies with worse policies.

Our results also suggest that the increased scope for effective aid absorption does not occur immediately. There is neither a supra-normal growth effect nor a supra-normal effect of aid in the peace onset period. Since the moment of peace onset is randomly distributed across the four-year peace-onset episode, its average length is two years. We have also found that there appears to be no supra normal growth effect during the first three years of peace, or beyond the seventh year of peace. Hence, there is some presumption that the key period during which aid absorption is exceptionally high is approximately between the fourth and the seventh year of peace. From the perspective of effective use of aid for economic recovery, aid volumes should gradually build up during the first few years of peace, and gradually revert to normal levels after around a decade. We should stress that. these results are tentative: as data for the episode 1998-2001 become available, the sample of post-conflict countries will increase and the results should be re-assessed.

With this caveat we now compare the proposed pattern of aid to post-conflict situations with the actual pattern. In Table 4 we change the dependent variable from growth to aid. In the baseline regression (column 1) aid is investigated as a function of per capita income, total population, region, policy, time period, and 'warmonths'. Unsurprisingly, 
donors sharply reduce aid during periods of active conflict. In the next three columns we introduce in turn variables for the three post-conflict episodes. The number of peaceonset months is positive but insignificant, suggesting that donors rapidly restore aid once peace is restored, at least to normal levels and perhaps in excess of normal levels. The dummies for the first and second full peace periods are negative and large with the latter being significant. Donors are at most funding at normal levels and, after an initial spurt, are phasing aid out even during this first decade of peace, reducing it below levels normal for other countries with similar circumstances.

An implication of the above analysis is that donors have not responded appropriately to post-conflict situations. The initial response during the peace-onset period - typically the first two years - has indeed restored lending, perhaps (on the narrow criterion of poverty reduction) even excessively, but thereafter aid should have continued to taper in whereas it has tended to taper out. This is consistent with other evidence that suggests that historically donors have not been very responsive to growth opportunities (Alesina and Dollar, 2000). The recent experiences of Afghanistan and East Timor suggest that donor behavior may be changing: the volume of aid allocated to post-conflict situations may well have increased substantially, which on our analysis would be appropriate. However, the timing of the inflow may not be appropriate, arriving too soon and tapering out too early. For example, the present rules concerning IDA allocation to post-conflict allow for supra-normal aid allocations only in the first three years of peace, which on our analysis is too early for effective absorption. Of course, the benchmarks provided by regression analysis, especially on such a small sample of episodes, can provide only limited guidance. Each situation will appropriately be assessed using much richer countryspecific information. However, given the highly politicized context of aid allocations in post-conflict situations, it would not be surprising if historically they have not been appropriately aligned with the opportunities for reinforcing economic recovery.

\section{Policy priorities during recovery}

We now turn to the question of whether policy priorities for growth should be distinctive in post-conflict societies. The previous analysis has already implicitly answered this at the aggregate level of policy captured by the overall CPIA rating, which is an average over ratings of twenty different particular policies. Since the effect of aid is dependent upon policy, as measured by the CPIA, the better is policy, the larger is the growth spurt. Thus, when policy reform is coordinated with aid flows, it is atypically effective in promoting growth in post-conflict situations. The previous analysis has also found that the interaction term between policy and the three post-conflict variables is insignificant. Hence, other than through its effects on enhancing aid absorption, policy is neither more nor less important for growth in post-conflict situations than in other situations. Policy matters more in post-conflict situations because it differentially augments the effectiveness of aid.

We now investigate whether particular policies are differentially important in postconflict situations. For this we disaggregate the overall policy rating into four 
components: macro, structural, social and governance. This disaggregation is dictated by the availability of data, but it corresponds to important broad categories of policy and so is potentially useful. The data on macro, structural and social policies are from the components of the CPIA ratings and are available since 1990. Prior to this the CPIA was only an aggregate indicator of policy. Within the CPIA each of these three components is scored on a scale, 1-5. Thus, if one component has a lower score than another this has no intrinsic meaning. However, in practice, the mean values of the three components are all very similar: during the 1990 s the average rating for macro policies was $4 \%$ higher than for structural policies, and $6 \%$ higher than for social policies. This suggests that each component of the scale was approximately ordinal, with a country that was average for macroeconomic policies, getting approximately the same rating on these policies as the rating for social policies for a country that was average for those policies. In addition to the CPIA, which is measured on a common basis by World Bank staff, the ICRGE is used to measure governance. Again, this is a subjective assessment on a scale of 1-6.

In Table 5 we compare post-conflict countries with all countries in respect of these four aspects of policy for the 1990s. The macro, structural and social policy scores are shown as relative to the overall CPIA score.

Unsurprisingly, post-conflict societies have worse CPIA scores than other societies. The scores by post-conflict episode reveal a steady improvement as long as peace is maintained. In the peace-onset period the CPIA is only 2.41 , in the first full period of peace it is 2.88, and in the second full peace period it has risen to 3.05 and so is in effect back to normal. Hence, the phase of distinctively problematic policy is the first 4-8 years post-conflict. However, although the level of overall policy is distinctively poor during this period, there appears to be no systematic difference between policies. Macro, structural and social policy scores are all equally discounted in post-conflict countries and show fairly uniform improvements during the three post-conflict periods. Governance, as measured by the ICRGE, is markedly worse during the peace onset period, than other developing countries. However, in contrast to the CPIA components, it actually appears to deteriorate over the ensuing decade.

We now return to the regression analysis, introducing terms which interact each of the four components of policy with a post-conflict dummy variable. This tests whether any of these policies is differentially important for growth in post-conflict situations and hence provides some guidance as to priorities for policy improvement. Since our analysis can only be conducted for the period since 1990 , the number of post-conflict observations is too small to permit disaggregation into the three distinct post-conflict episodes analyzed above so that the post-conflict dummy refers to all three episodes.

In Table 6, column 1 we add the interaction term for governance. The interaction term is insignificant, so that governance is approximately as important for growth in post-conflict situations as in other contexts.

Macro, structural and social policy scores on the CPIA are too highly correlated with the overall CPIA to be entered together in the same regression. To overcome this problem, 
we measure each relative to the average CPIA score. Thus, we retain the overall CPIA score in the regression and add variables showing how the components deviate from the overall score. Evidently, since the overall score is simply the average of its three components, once the deviation of any two of the components from the average is specified, the deviation of the third component is also determined. Hence, only two of the deviations in the components can be entered together in the regression. In Table 6 column 2 we introduce the deviations for the macro and social components of the CPIA as additional variables, and also the interactions of these terms - with the post-conflict dummy, so that structural policies are the excluded term and so the benchmark.

Since the regression is run for all episodes since 1974, but the disaggregated CPIA data is only available for the 1990s, we initially include both a dummy variable for the 1990 s and an interaction of this dummy with the overall CPIA score. This allows both that exogenous growth might have been different during this period and that the effect of policy might have been different. Without these terms the CPIA component terms might be spuriously picking up such effects. In the event, neither term is significant and they are dropped from the regression.

The regression includes the direct effect of the macro and social components of the CPIA (i.e. without being interacted with the post-conflict dummy). These terms are necessary in order to determine how the effects of these components of policy are distinctive in postconflict situations, through their interaction with the post-conflict dummy. However, the temptation to interpret these direct effects as showing which components of policy are most important for growth outside the context of post-conflict should be resisted. All they show is what would happen if the three component parts of the CPIA score were to be varied in such a way as to keep the aggregate score constant. At the most, these results will tell us that the reforms represented by $a$ one point increase in one component are more valuable for growth than the reforms represented by $a$ one point increase in another component. They are therefore a comment not upon the relative importance of macro, structural and social policies, but upon the scoring systems for them. There is no reason why a one point change in one component should be in any sense commensurate with a one point increase in another component.

While the direct effects of the three policy components must therefore be dismissed, the variables generated by interacting the policy components with the post-conflict dummy are readily interpretable. They test for whether policy priorities should be distinctive in post-conflict situations when compared to other circumstances. Both the interaction terms are significant, with macro negative and social positive. Further, the coefficients on both terms are large. Given the objective of promoting growth, consider priorities as between macro, structural and social reforms in two societies with identical CPIA scores on each component, one society being post-conflict and the other having no history of conflict. The results tell us that the post-conflict society should pay more attention to improvements in social policy than the other society, and less attention to improvements in macro policy. This formulation of the result is not only meaningful, it is pertinent. Post-conflict situations constitute only a small minority of the situations on which IFI experience is based. Hence, in the absence of such knowledge, IFI staff are likely to 
advise for post-conflict situations those policy priorities that are effective in normal circumstances. While the broad direction of such advice might be correct, our results suggest that priorities based on general experience are likely to be misplaced. For example, suppose that a post-conflict society starts with each component - macro, structural and social - rated at 2.5, and the matter for judgment is whether a small improvement in social policies at the expense of a small deterioration in macroeconomic policies would be advisable from the perspective of growth. To be specific, let these small changes in policy amount to an improvement in social policies to 2.6 and a deterioration in macroeconomic policies to 2.4. The coefficients on the direct effects of these components of policy suggest that were the situation not post-conflict, such a change would reduce growth. By contrast, in a post-conflict situation growth would be increased by around one percentage point.

We can also distinguish to an extent between the two possible ways by which policy priorities might be distinctive - differential severity of policy problems and differential effects of policies. Recall that the three components of the CPIA are all equally poor in post-conflict situations. There does not appear to be differential deterioration. Hence, it appears that the differential importance of social policy is not because social policies are differentially bad in post-conflict situations, but rather that they are differentially important. This is indeed consistent with much of the practical policy work in postconflict situations which tends to prioritize social issues. However, recall from Table 5 that the policy ratings tend to improve through the various phases of post-conflict in tandem. Our analysis suggests that it would be desirable if social policy could improve at a faster rate than structural policy, which in turn should improve at a faster rate than macro policy. This is decidedly not to say that macro does not matter. In post-conflict, as elsewhere, everything matters. But the practical process of reform is always a matter of priorities.

\section{Conclusion}

Countries coming out of conflict are in atypical need of both financial resources and policy advice. Their societies are often extremely fragile and so it is important that the response of the international development community should be as appropriate as possible. Although such situations are becoming more common, they still constitute a small minority of development experience, and so there is a danger that they will receive both finance and advice that largely ignores their special characteristics. Most donors now have units specially dedicated to post-conflict, but to date the learning process has largely been highly context-specific. Indeed, a common assessment from policy practitioners is that each situation is so distinctive that there are no general lessons. In this paper we have investigated post-conflict economic recovery statistically, using all episodes for which data are available. Since the number of such observations is quite limited, the degree of confidence in the results must be correspondingly discounted. The basis for our analysis has' been to incorporate post-conflict situations explicitly into the existing analysis of the relationship between aid, policy and growth as undertaken in Collier and Dollar (2002). Two general patterns have emerged from this analysis. 
First, we find that aid is considerably more effective in augmenting growth in postconflict situations than in other situations. For 'poverty efficiency', aid volumes should be approximately double those in other situations. The pattern of aid disbursements should probably gradually rise during the first four years, and gradually taper back to normal levels by the end of the first post-conflict decade. Actual aid practice has not, historically, followed this pattern.

Second, we find that among policies the key priorities for improvement, relative to an otherwise similar society without a history of recent conflict, should be social policies first, sectoral policies second, broadly with the same priority as in other contexts, and macro policies last. Again, actual improvements in policies during the first decade of peace do not appear to reflect these priorities: all policies other than governance appear to improve more or less in tandem. 


\section{References}

Alesina, Alberto and David Dollar. 2000. "Who Gives Foreign Aid to Whom and Why?" Journal of Economic Growth, 5: 33-63.

Burnside, Craig and David Dollar. 2001. "Aid, Policy and Growth" American Economic Review, 90: 847-868.

Collier, Paul. 1999. "On the Economic Consequences of Civil War," Oxford Economic Papers, 51: 168-183.

Collier, Paul and David Dollar. 2002. "Aid Allocation and Poverty Reduction," European Economic Review 46: 1475-1500.

Collier, Paul and Anke Hoeffler. 2002. "Aid, Policy and Peace: Reducing the Risks of Civil Conflict," Journal of Defense Economics and Peace, (forthcoming). . 2002a. "Greed and Grievance in Civil War." WPS 2002-01, Centre for the Study of African Economies Working Paper

Tirole, Jean. 1992. "Persistence of Corruption, Institute for Policy Reform," Working Paper 55, Washington D.C. 
Table 1: The Pattern of Post-Conflict Recovery

\begin{tabular}{|c|c|c|c|c|c|}
\hline & (1) & (2) & (3) & (4) & (5) \\
\hline Initial per capita income & $\begin{array}{l}0.725 \\
(0.620)\end{array}$ & $\begin{array}{l}0.738 \\
(0.619)\end{array}$ & $\begin{array}{l}0.699 \\
(0.623)\end{array}$ & $\begin{array}{l}0.727 \\
(0.619)\end{array}$ & $\begin{array}{l}0.717 \\
(0.620)\end{array}$ \\
\hline Governance (ICRGE) & $\begin{array}{l}0.146 \\
(0.159)\end{array}$ & $\begin{array}{l}0.232 \\
(0.156)\end{array}$ & $\begin{array}{l}0.136 \\
(0.160)\end{array}$ & $\begin{array}{l}0.212 \\
(0.155)\end{array}$ & $\begin{array}{l}0.175 \\
(0.160)\end{array}$ \\
\hline CPIA & $\begin{array}{l}1.027 \\
(0.396)^{* * *}\end{array}$ & $\begin{array}{l}0.959 \\
(0.396)^{* *}\end{array}$ & $\begin{array}{l}1.006 \\
(0.392)^{* *}\end{array}$ & $\begin{array}{l}0.957 \\
(0.392)^{* *}\end{array}$ & $\begin{array}{l}0.992 \\
(0.397)^{* *}\end{array}$ \\
\hline (ODA/GDP) $\times$ CPIA & $\begin{array}{l}0.145 \\
(0.065)^{* *}\end{array}$ & $\begin{array}{l}0.157 \\
(0.065)^{* *}\end{array}$ & $\begin{array}{l}0.142 \\
(0.066)^{* *}\end{array}$ & $\begin{array}{l}0.151 \\
(0.064)^{* *}\end{array}$ & $\begin{array}{l}0.150 \\
(0.065)^{* *}\end{array}$ \\
\hline$(\mathrm{ODA} / \mathrm{GDP})^{2}$ & $\begin{array}{l}-0.029 \\
(0.013)^{* *}\end{array}$ & $\begin{array}{l}-0.031 \\
(0.013)^{* *}\end{array}$ & $\begin{array}{l}-0.029 \\
(0.013)^{* *}\end{array}$ & $\begin{array}{l}-0.030 \\
(0.012)^{* *}\end{array}$ & $\begin{array}{l}-0.029 \\
(0.013)^{* *}\end{array}$ \\
\hline South Asia & $\begin{array}{l}2.657 \\
(0.623)^{* * *}\end{array}$ & $\begin{array}{l}2.488 \\
(0.627)^{* * *}\end{array}$ & $\begin{array}{l}2.691 \\
(0.629)^{* * *}\end{array}$ & $\begin{array}{l}2.572 \\
(0.626)^{* * *}\end{array}$ & $\begin{array}{l}2.569 \\
(0.620)^{* * *}\end{array}$ \\
\hline East Asia & $\begin{array}{l}2.886 \\
(0.662)^{* * *}\end{array}$ & $\begin{array}{l}2.823 \\
(0.660)^{* * *}\end{array}$ & $\begin{array}{l}2.952 \\
(0.652)^{* * *}\end{array}$ & $\begin{array}{l}2.891 \\
(0.662)^{* * *}\end{array}$ & $\begin{array}{l}2.870 \\
(0.659)^{* * *}\end{array}$ \\
\hline Sub-Saharan Africa & $\begin{array}{l}-0.502 \\
(0.812)\end{array}$ & $\begin{array}{l}-0.612 \\
(0.807)\end{array}$ & $\begin{array}{l}-0.514 \\
(0.816)\end{array}$ & $\begin{array}{l}-0.589 \\
(0.797)\end{array}$ & $\begin{array}{l}-0.578 \\
(0.811)\end{array}$ \\
\hline Middle East/ North Africa & $\begin{array}{l}1.546 \\
(0.554)^{* * *}\end{array}$ & $\begin{array}{l}1.516 \\
(0.562)^{* * *}\end{array}$ & $\begin{array}{l}1.569 \\
(0.556)^{* * *}\end{array}$ & $\begin{array}{l}1.543 \\
(0.565)^{* * *}\end{array}$ & $\begin{array}{l}1.512 \\
(0.554)^{* * *}\end{array}$ \\
\hline Europe/Central Asia & $\begin{array}{l}-0.347 \\
(1.055)\end{array}$ & $\begin{array}{l}-0.440 \\
(1.046)\end{array}$ & $\begin{array}{l}-0.287 \\
(1.063)\end{array}$ & $\begin{array}{l}-0.436 \\
(1.053)\end{array}$ & $\begin{array}{l}-0.387 \\
(1.050)\end{array}$ \\
\hline Post-conflict $0-2$ & & $\begin{array}{l}1.133 \\
(0.605)^{*}\end{array}$ & & & \\
\hline War months & . & & $\begin{array}{l}-0.007 \\
(0.011)\end{array}$ & & \\
\hline Peace-onset & & & $\begin{array}{l}0.113 \\
(1.114)\end{array}$ & & \\
\hline Post-conflict 1 & & & & $\begin{array}{l}1.889 \\
(0.763)^{* *}\end{array}$ & \\
\hline Post-conflict 2 & & & & & $\begin{array}{l}1.158 \\
(0.815)\end{array}$ \\
\hline $\begin{array}{l}\text { Observations } \\
\text { Post-conflict observations } \\
\mathbf{R}^{2}\end{array}$ & $\begin{array}{l}344 \\
34 \\
0.37 \\
\end{array}$ & $\begin{array}{l}344 \\
34 \\
0.37 \\
\end{array}$ & $\begin{array}{l}344 \\
13 \\
0.37 \\
\end{array}$ & $\begin{array}{l}344 \\
13 \\
0.37 \\
\end{array}$ & $\begin{array}{l}344 \\
8 \\
0.37 \\
\end{array}$ \\
\hline
\end{tabular}

Note: Robust standard errors in parentheses. * significant at $10 \%$; ** significant at $5 \%$; *** significant at $1 \%$. All regressions include time dummies which are jointly significant. 
Table 2: Year by Year Examination of Post-Conflict Recovery

\begin{tabular}{|c|c|c|c|c|c|c|c|c|c|}
\hline & (1) & (2) & (3) & (4) & (5) & (6) & (7) & (8) & (9) \\
\hline $\begin{array}{l}\text { Initial per } \\
\text { capita income }\end{array}$ & $\begin{array}{l}0.727 \\
(0.620)\end{array}$ & $\begin{array}{l}0.722 \\
(0.622)\end{array}$ & $\begin{array}{l}0.728 \\
(0.622)\end{array}$ & $\begin{array}{l}0.733 \\
(0.620)\end{array}$ & $\begin{array}{l}0.727 \\
(0.619)\end{array}$ & $\begin{array}{l}0.726 \\
(0.619)\end{array}$ & $\begin{array}{l}0.723 \\
(0.619)\end{array}$ & $\begin{array}{l}0.731 \\
(0.621)\end{array}$ & $\begin{array}{l}0.718 \\
(0.618)\end{array}$ \\
\hline $\begin{array}{l}\text { Governance } \\
\text { (ICRGE) }\end{array}$ & $\begin{array}{l}0.158 \\
(0.161)\end{array}$ & $\begin{array}{l}0.143 \\
(0.160)\end{array}$ & $\begin{array}{l}0.156 \\
(0.155)\end{array}$ & $\begin{array}{l}0.187 \\
(0.156)\end{array}$ & $\begin{array}{l}0.212 \\
(0.155)\end{array}$ & $\begin{array}{l}0.228 \\
(0.155)\end{array}$ & $\begin{array}{l}0.194 \\
(0.160)\end{array}$ & $\begin{array}{l}0.180 \\
(0.158)\end{array}$ & $\begin{array}{l}0.236 \\
(0.156)\end{array}$ \\
\hline CPIA & $\begin{array}{l}1.034 \\
(0.395)^{* * *}\end{array}$ & $\begin{array}{l}1.025 \\
(0.395)^{* * *}\end{array}$ & $\begin{array}{l}1.019 \\
(0.397)^{* *}\end{array}$ & $\begin{array}{l}0.986 \\
(0.393)^{* *}\end{array}$ & $\begin{array}{l}0.957 \\
(0.392)^{* *}\end{array}$ & $\begin{array}{l}0.931 \\
(0.393)^{* *}\end{array}$ & $\begin{array}{l}0.979 \\
(0.396)^{* *}\end{array}$ & $\begin{array}{l}1.009 \\
(0.396)\end{array}$ & $\begin{array}{l}0.954 \\
(0.391)^{* *}\end{array}$ \\
\hline $\begin{array}{l}\text { (ODA/GDP) } x \\
\text { CPIA }\end{array}$ & $\begin{array}{l}0.146 \\
(0.065)^{* *}\end{array}$ & $\begin{array}{l}0.145 \\
(0.066)^{* *}\end{array}$ & $\begin{array}{l}0.147 \\
(0.066)^{* *}\end{array}$ & $\begin{array}{l}0.151 \\
(0.065)^{* *}\end{array}$ & $\begin{array}{l}0.151 \\
(0.064)^{* *}\end{array}$ & $\begin{array}{l}0.154 \\
(0.063)^{* *}\end{array}$ & $\begin{array}{l}0.152 \\
(0.064)^{* *}\end{array}$ & $\begin{array}{l}0.150 \\
(0.066)^{* *}\end{array}$ & $\begin{array}{l}0.155 \\
(0.063)^{* *}\end{array}$ \\
\hline$(\mathrm{ODA} / \mathrm{GDP})^{2}$ & $\begin{array}{l}-0.029 \\
(0.013)^{* *}\end{array}$ & $\begin{array}{l}-0.029 \\
(0.013)^{* *}\end{array}$ & $\begin{array}{l}-0.029 \\
(0.013)^{* *}\end{array}$ & $\begin{array}{l}-0.030 \\
(0.013)^{* *}\end{array}$ & $\begin{array}{l}-0.030 \\
(0.012)^{* *}\end{array}$ & $\begin{array}{l}-0.030 \\
(0.012)^{* *}\end{array}$ & $\begin{array}{l}-0.030 \\
(0.012)^{* *}\end{array}$ & $\begin{array}{l}-0.029 \\
(0.013)^{* *}\end{array}$ & $\begin{array}{l}-0.031 \\
(0.012)^{* *}\end{array}$ \\
\hline South Asia & $\begin{array}{l}2.669 \\
(0.626) * * *\end{array}$ & $\begin{array}{l}2.657 \\
(0.624)^{* * *}\end{array}$ & $\begin{array}{l}2.660 \\
(0.622)^{* \cdots+\cdots}\end{array}$ & $\begin{array}{l}2.612 \\
(0.624)^{* * * *}\end{array}$ & $\begin{array}{l}2.572 \\
(0.626)^{* * *}\end{array}$ & $\begin{array}{l}2.559 \\
(0.626)^{* * *}\end{array}$ & $\begin{array}{l}2.551 \\
(0.624)^{* * *}\end{array}$ & $\begin{array}{l}2.653 \\
(0.625)^{* * *}\end{array}$ & $\begin{array}{l}2.573 \\
(0.618)^{* * *}\end{array}$ \\
\hline East Asia & $\begin{array}{l}2.857 \\
(0.668)^{* \ldots *}\end{array}$ & $\begin{array}{l}2.891 \\
(0.665)^{* * *}\end{array}$ & $\begin{array}{l}2.887 \\
(0.663)^{* * *}\end{array}$ & $\begin{array}{l}2.893 \\
(0.662)^{* * *}\end{array}$ & $\begin{array}{l}2.891 \\
(0.662)^{* * *}\end{array}$ & $\begin{array}{l}2.905 \\
(0.661)^{* * * *}\end{array}$ & $\begin{array}{l}2.864 \\
(0.657)^{* * * *}\end{array}$ & $\begin{array}{l}2.852 \\
(0.666)^{* * *}\end{array}$ & $\begin{array}{l}2.869 \\
(0.656)^{* * *}\end{array}$ \\
\hline $\begin{array}{l}\text { Sub-Saharan } \\
\text { Africa }\end{array}$ & $\begin{array}{l}-0.494 \\
(0.813)\end{array}$ & $\begin{array}{l}-0.504 \\
(0.812)\end{array}$ & $\begin{array}{l}-0.507 \\
(0.811)\end{array}$ & $\begin{array}{l}-0.558 \\
(0.807)\end{array}$ & $\begin{array}{l}-0.589 \\
(0.797)\end{array}$ & $\begin{array}{l}-0.618 \\
(0.796)\end{array}$ & $\begin{array}{l}-0.604 \\
(0.810)\end{array}$ & $\begin{array}{l}-0.529 \\
(0.811)\end{array}$ & $\begin{array}{l}-0.615 \\
(0.801)\end{array}$ \\
\hline $\begin{array}{l}\text { Middle East } \\
\text { North Africa }\end{array}$ & $\begin{array}{l}1.569 \\
(0.553)^{* * *}\end{array}$ & $\begin{array}{l}1.547 \\
(0.554)^{* * * *}\end{array}$ & $\begin{array}{l}1.548 \\
(0.556)^{* * *}\end{array}$ & $\begin{array}{l}1.545 \\
(0.562)^{* * *}\end{array}$ & $\begin{array}{l}1.543 \\
(0.565)^{* * *}\end{array}$ & $\begin{array}{l}1.538 \\
(0.553)^{* \ldots \ldots}\end{array}$ & $\begin{array}{l}1.514 \\
(0.554)^{* * *}\end{array}$ & $\begin{array}{l}1.542 \\
(0.559)^{* * *}\end{array}$ & $\begin{array}{l}1.535 \\
(0.562)^{* * *}\end{array}$ \\
\hline $\begin{array}{l}\text { Europe/Central } \\
\text { Asia }\end{array}$ & $\begin{array}{l}-0.351 \\
(1.054)\end{array}$ & $\begin{array}{l}-0.345 \\
(1.058)\end{array}$ & $\begin{array}{l}-0.359 \\
(1.053)\end{array}$ & $\begin{array}{l}-0.400 \\
(1.051)\end{array}$ & $\begin{array}{l}-0.436 \\
(1.053)\end{array}$ & $\begin{array}{l}-0.439 \\
(1.062)\end{array}$ & $\begin{array}{l}-0.410 \\
(1.047)\end{array}$ & $\begin{array}{l}-0.382 \\
(1.054)\end{array}$ & $\begin{array}{l}-0.449 \\
(1.045)\end{array}$ \\
\hline $\begin{array}{l}\text { First post- } \\
\text { conflict year }\end{array}$ & $\begin{array}{l}0.071 \\
(0.131)\end{array}$ & & & & & & & & \\
\hline $\begin{array}{l}\text { Second post- } \\
\text { conflict year }\end{array}$ & & $\begin{array}{l}-0.017 \\
(0.110)\end{array}$ & & & & & & & \\
\hline $\begin{array}{l}\text { Third post- } \\
\text { conflict year }\end{array}$ & & & $\begin{array}{l}0.029 \\
(0.098)\end{array}$ & & & & & & \\
\hline $\begin{array}{l}\text { Fourth post- } \\
\text { conflict year }\end{array}$ & & & & $\begin{array}{l}0.099 \\
(0.064)\end{array}$ & & & & & \\
\hline $\begin{array}{l}\text { Fifth post- } \\
\text { conflict year }\end{array}$ & & & & & $\begin{array}{l}0.157 \\
(0.064)^{* *}\end{array}$ & & & & \\
\hline $\begin{array}{l}\text { Sixth post- } \\
\text { conflict year }\end{array}$ & & & & & & $\begin{array}{l}0.182 \\
(0.058)^{* * *}\end{array}$ & & & \\
\hline $\begin{array}{l}\text { Seventh post- } \\
\text { conflict year }\end{array}$ & & & & & & & $\begin{array}{l}0.143 \\
(0.062)^{* *}\end{array}$ & & \\
\hline $\begin{array}{l}\text { first three post- } \\
\text { conflict years }\end{array}$ & & & & & & & & $\begin{array}{l}0.674 \\
(0.821)\end{array}$ & \\
\hline $\begin{array}{l}\text { fourth -seventh } \\
\text { post-c. year }\end{array}$ & & & & & & & & & $\begin{array}{l}1.464 \\
(0.573)^{* *}\end{array}$ \\
\hline $\begin{array}{l}\text { Observations } \\
\text { p.-conflict obs. } \\
\mathrm{R}^{2}\end{array}$ & $\begin{array}{l}344 \\
13 \\
0.37 \\
\end{array}$ & $\begin{array}{l}344 \\
13 \\
0.37 \\
\end{array}$ & $\begin{array}{l}344 \\
13 \\
0.37 \\
\end{array}$ & $\begin{array}{l}344 \\
13 \\
0.37 \\
\end{array}$ & $\begin{array}{l}344 \\
13 \\
0.37 \\
\end{array}$ & $\begin{array}{l}344 \\
13 \\
0.38 \\
\end{array}$ & $\begin{array}{l}344 \\
13 \\
0.37 \\
\end{array}$ & $\begin{array}{l}344 \\
13 \\
0.37 \\
\end{array}$ & $\begin{array}{l}344 \\
13 \\
0.37 \\
\end{array}$ \\
\hline
\end{tabular}

Note: Robust standard errors in parentheses. " significant at $10 \%$; ${ }^{* *}$ significant at $5 \%$; ${ }^{* * *}$ significant at $1 \%$. All regressions include time dummies which are jointly significant. 
Table 3: Interaction Effects

\begin{tabular}{|c|c|c|c|c|c|c|c|c|}
\hline & (1) & (2) & (3) & (4) & $(5)$ & (6) & (7) & (8) \\
\hline $\begin{array}{l}\text { Initial per } \\
\text { capita income }\end{array}$ & $\begin{array}{l}0.718 \\
(0.627)\end{array}$ & $\begin{array}{l}0.715 \\
(0.621)\end{array}$ & $\begin{array}{l}0.717 \\
(0.618)\end{array}$ & $\begin{array}{l}0.712 \\
(0.617)\end{array}$ & $\begin{array}{l}0.718 \\
(0.629)\end{array}$ & $\begin{array}{l}0.719 \\
(0.627)\end{array}$ & $\begin{array}{l}0.715 \\
(0.625)\end{array}$ & $\begin{array}{l}0.711 \\
(0.624)\end{array}$ \\
\hline $\begin{array}{l}\text { Governance } \\
\text { (ICRGE) }\end{array}$ & $\begin{array}{l}0.196 \\
(0.160)\end{array}$ & $\begin{array}{l}0.197 \\
(0.157)\end{array}$ & $\begin{array}{l}0.198 \\
(0.157)\end{array}$ & $\begin{array}{l}0.172 \\
(0.155)\end{array}$ & $\begin{array}{l}0.158 \\
(0.160)\end{array}$ & $\begin{array}{l}0.158 \\
(0.160)\end{array}$ & $\begin{array}{l}0.153 \\
(0.161)\end{array}$ & $\begin{array}{l}0.147 \\
(0.160)\end{array}$ \\
\hline cpia & $\begin{array}{l}0.991 \\
(0.397)^{* *}\end{array}$ & $\begin{array}{l}0.991 \\
(0.396)^{* *}\end{array}$ & $\begin{array}{l}0.988 \\
(0.390)^{* *}\end{array}$ & $\begin{array}{l}1.021 \\
(0.392)^{* * *}\end{array}$ & $\begin{array}{l}0.996 \\
(0.402)^{* *}\end{array}$ & $\begin{array}{l}0.999 \\
(0.401)^{* *}\end{array}$ & $\begin{array}{l}1.017 \\
(0.396)^{* *}\end{array}$ & $\begin{array}{l}1.017 \\
(0.396)^{* *}\end{array}$ \\
\hline odacpiac & $\begin{array}{l}0.134 \\
(0.066)^{* *}\end{array}$ & $\begin{array}{l}0.134 \\
(0.066)^{* *}\end{array}$ & $\begin{array}{l}0.134 \\
(0.065)^{* *}\end{array}$ & $\begin{array}{l}0.127 \\
(0.064)^{*}\end{array}$ & $\begin{array}{l}0.151 \\
(0.066)^{* *}\end{array}$ & $\begin{array}{l}0.148 \\
(0.066)^{* *}\end{array}$ & $\begin{array}{l}0.148 \\
(0.066)^{* *}\end{array}$ & $\begin{array}{l}0.147 \\
(0.065)^{* *}\end{array}$ \\
\hline$(\mathrm{ODA} / G D P)^{2}$ & $\begin{array}{l}-0.028 \\
(0.012)^{* *}\end{array}$ & $\begin{array}{l}-0.028 \\
(0: 01.2)^{* *}\end{array}$ & $\begin{array}{l}-0.028 \\
(0.012)^{* *}\end{array}$ & $\begin{array}{l}-0.028 \\
(0.012)^{* *}\end{array}$ & $\begin{array}{l}-0.029 \\
(0.013)^{* *}\end{array}$ & $\begin{array}{l}-0.029 \\
(0.013)^{* *}\end{array}$ & $\begin{array}{l}-0.029 \\
(0.013)^{* *}\end{array}$ & $\begin{array}{l}-0.028 \\
(0.013)^{* *}\end{array}$ \\
\hline South Asia & $\begin{array}{l}2.614 \\
(0.644)^{* * *}\end{array}$ & $\begin{array}{l}2.611 \\
(0.639)^{* * *}\end{array}$ & $\begin{array}{l}2.619 \\
(0.625)^{* * *}\end{array}$ & $\begin{array}{l}2.662 \\
(0.620)^{* * *}\end{array}$ & $\begin{array}{l}2.605 \\
(0.629)^{* * *}\end{array}$ & $\begin{array}{l}2.623 \\
(0.629)^{* * *}\end{array}$ & $\begin{array}{l}2.618 \\
(0.630)^{* * *}\end{array}$ & $\begin{array}{l}2.633 \\
(0.626)^{* * *}\end{array}$ \\
\hline East Asia & $\begin{array}{l}2.891 \\
(0.663)^{* * *}\end{array}$ & $\begin{array}{l}2.889 \\
(0.660)^{* * *}\end{array}$ & $\begin{array}{l}2.884 \\
(0.660) * * *\end{array}$ & $\begin{array}{l}2.880 \\
(0.660)^{* * * *}\end{array}$ & $\begin{array}{l}2.847 \\
(0.668)^{* * *}\end{array}$ & $\begin{array}{l}2.855 \\
(0.667)^{* * *}\end{array}$ & $\begin{array}{l}2.866 \\
(0.668)^{* * *}\end{array}$ & $\begin{array}{l}2.883 \\
(0.664)^{* * *}\end{array}$ \\
\hline $\begin{array}{l}\text { Sub-Saharan } \\
\text { Africa }\end{array}$ & $\begin{array}{l}-0.440 \\
(0.821)\end{array}$ & $\begin{array}{l}-0.442 \\
(0.817)\end{array}$ & $\begin{array}{l}-0.442 \\
(0.816)\end{array}$ & $\begin{array}{l}-0.366 \\
(0.809)\end{array}$ & $\begin{array}{l}-0.569 \\
(0.830)\end{array}$ & $\begin{array}{l}-0.545 \\
(0.827)\end{array}$ & $\begin{array}{l}-0.556 \\
(0.820)\end{array}$ & $\begin{array}{l}-0.550 \\
(0.817)\end{array}$ \\
\hline $\begin{array}{l}\text { Middle East/ } \\
\text { North Africa }\end{array}$ & $\begin{array}{l}1.590 \\
(0.568)^{* * *}\end{array}$ & $\begin{array}{l}1.591 \\
(0.567)^{* * *}\end{array}$ & $\begin{array}{l}1.589 \\
(0.567)^{* * *}\end{array}$ & $\begin{array}{l}1.606 \\
(0.563)^{* * *}\end{array}$ & $\begin{array}{l}1.506 \\
(0.552)^{* * *}\end{array}$ & $\begin{array}{l}1.515 \\
(0.554)^{* * *}\end{array}$ & $\begin{array}{l}1.520 \\
(0.556)^{* * *}\end{array}$ & $\begin{array}{l}1.524 \\
(0.553)^{* * *}\end{array}$ \\
\hline $\begin{array}{l}\text { Europe/ } \\
\text { Central Asia }\end{array}$ & $\begin{array}{l}-0.400 \\
(1.059)\end{array}$ & $\begin{array}{l}-0.402 \\
(1.056)\end{array}$ & $\begin{array}{l}-0.403 \\
(1.054)\end{array}$ & $\begin{array}{l}-0.365 \\
(1.053)\end{array}$ & $\begin{array}{l}-0.353 \\
(1.074)\end{array}$ & $\begin{array}{l}-0.355 \\
(1.068)\end{array}$ & $\begin{array}{l}-0.354 \\
(1.067)\end{array}$ & $\begin{array}{l}-0.352 \\
(1.064)\end{array}$ \\
\hline post-conflict 1 & $\begin{array}{l}1.385 \\
(3.237)\end{array}$ & $\begin{array}{l}1.445 \\
(3.073)\end{array}$ & $\begin{array}{l}0.913 \\
(0.755)\end{array}$ & & & & & \\
\hline $\begin{array}{l}\text { post-conflictl } \\
\text { x CPLA }\end{array}$ & $\begin{array}{l}-0.186 \\
(1.011)\end{array}$ & $\begin{array}{l}-0.180 \\
(1.019)\end{array}$ & & & & & & \\
\hline $\begin{array}{l}\text { post-conflictlx } \\
\text { (ODA/GDP) }^{2}\end{array}$ & $\begin{array}{l}-0.009 \\
(0.102)\end{array}$ & & & & & & & \\
\hline $\begin{array}{l}\text { post-conflictl } \\
\text { x (ODA/GDP) x } \\
\text { CPIA }\end{array}$ & $\begin{array}{l}0.168 \\
(0.330)\end{array}$ & $\begin{array}{l}0.141 \\
(0.042)^{* * *}\end{array}$ & $\begin{array}{l}0.139 \\
(0.041)^{* * *}\end{array}$ & $\begin{array}{l}0.186 \\
(0.046)^{* * *}\end{array}$ & & & & \\
\hline $\begin{array}{l}\text { peace-onset } x \\
\text { (ODA/GDP) }^{2}\end{array}$ & & & & & $\begin{array}{l}0.033 \\
(0.231)\end{array}$ & $\begin{array}{l}-0.031 \\
(0.027)\end{array}$ & $\begin{array}{l}-0.033 \\
(0.021)\end{array}$ & $\begin{array}{l}-0.027 \\
(0.019)\end{array}$ \\
\hline peace-onset & & & & & $\begin{array}{l}-0.594 \\
(5.531)\end{array}$ & $\begin{array}{l}-1.102 \\
(5.579)\end{array}$ & $\begin{array}{l}0.352 \\
(1.179)\end{array}$ & \\
\hline $\begin{array}{l}\text { peace-onset x } \\
\text { CPIA }\end{array}$ & & & & & $\begin{array}{l}0.502 \\
(1.648)\end{array}$ & $\begin{array}{l}0.516 \\
(1.691)\end{array}$ & & \\
\hline $\begin{array}{l}\text { peace-0. x (ODA } \\
\text { /GDP) x CPIA } \\
\text { post-conflict } 2\end{array}$ & & & & & $\begin{array}{l}-0.223 \\
(0.800)\end{array}$ & & & \\
\hline $\begin{array}{l}\text { post-conflict } 2 \\
x \text { CPIA }\end{array}$ & & & & & & & & \\
\hline $\begin{array}{l}\text { post-conflict2 } \\
x(\text { ODA/GDP })^{2}\end{array}$ & & & & & & & & \\
\hline $\begin{array}{l}\text { post-c. } 2 \times \text { (ODA } \\
\text { /GDP) } \times \text { CPIA }\end{array}$ & & & & & & & & \\
\hline $\begin{array}{l}\text { Observations } \\
\text { p.-conflict obs. }\end{array}$ & $\begin{array}{l}344 \\
13\end{array}$ & $\begin{array}{l}344 \\
13\end{array}$ & $\begin{array}{l}344 \\
13\end{array}$ & $\begin{array}{l}344 \\
13\end{array}$ & $\begin{array}{l}344 \\
13\end{array}$ & $\begin{array}{l}344 \\
13\end{array}$ & $\begin{array}{l}344 \\
13\end{array}$ & $\begin{array}{l}344 \\
13\end{array}$ \\
\hline $\mathbf{R}^{2}$ & 0.38 & 0.38 & 0.38 & 0.38 & 0.37 & 0.37 & 0.37 & 0.37 \\
\hline
\end{tabular}

Note: Robust standard errors in parentheses. * significant at $10 \%$; * significant at $5 \%$; ** significant at $1 \%$. All regressions include time dummies which are jointly significant. 
Table 4: Aid Allocation

\begin{tabular}{|c|c|c|c|c|}
\hline & (1) & (2) & (3) & (4) \\
\hline initial per capita income & $\begin{array}{l}-2.329 \\
(0.241)^{* * *}\end{array}$ & $\begin{array}{l}-2.329 \\
(0.241)^{* * *}\end{array}$ & $\begin{array}{l}-2.324 \\
(0.242)^{* * *}\end{array}$ & $\begin{array}{l}-2.304 \\
(0.239)^{* * *}\end{array}$ \\
\hline In Population & $\begin{array}{l}-0.717 \\
(0.080)^{* * *}\end{array}$ & $\begin{array}{l}-0.719 \\
(0.081)^{* * *}\end{array}$ & $\begin{array}{l}-0.712 \\
(0.081)^{* * *}\end{array}$ & $\begin{array}{l}-0.708 \\
(0.080)^{* * *}\end{array}$ \\
\hline governance (ICRGE) & $\begin{array}{l}0.001 \\
(0.082)\end{array}$ & $\begin{array}{l}0.005 \\
(0.082)\end{array}$ & $\begin{array}{l}-0.013 \\
(0.082)\end{array}$ & $\begin{array}{l}-0.025 \\
(0.083)\end{array}$ \\
\hline CPIA & $\begin{array}{l}0.274 \\
(0.126)^{* *}\end{array}$ & $\begin{array}{l}0.277 \\
(0.126)^{* *}\end{array}$ & $\begin{array}{l}0.282 \\
(0.124)^{* *}\end{array}$ & $\begin{array}{l}0.288 \\
(0.127)^{* *}\end{array}$ \\
\hline South Asia & $\begin{array}{l}-0.203 \\
(0.274)\end{array}$ & $\begin{array}{l}-0.205 \\
(0.272)\end{array}$ & $\begin{array}{l}-0.187 \\
(0.280)\end{array}$ & $\begin{array}{l}-0.119 \\
(0.279)\end{array}$ \\
\hline East Asia & $\begin{array}{l}0.061 \\
(0.206)\end{array}$ & $\begin{array}{l}0.054 \\
(0.208)\end{array}$ & $\begin{array}{l}0.065 \\
(0.206)\end{array}$ & $\begin{array}{l}0.095 \\
(0.205)\end{array}$ \\
\hline Sub-Saharan Africa & $\begin{array}{l}0.376 \\
(0.370)\end{array}$ & $\begin{array}{l}0.378 \\
(0.370)\end{array}$ & $\begin{array}{l}0.390 \\
(0.376)\end{array}$ & $\begin{array}{l}0.432 \\
(0.369)\end{array}$ \\
\hline Middle East/ North Africa & $\begin{array}{l}0.655 \\
(0.319)^{* *}\end{array}$ & $\begin{array}{l}0.661 \\
(0.321)^{* *}\end{array}$ & $\begin{array}{l}0.653 \\
(0.317)^{* *}\end{array}$ & $\begin{array}{l}0.679 \\
(0.317)^{* *}\end{array}$ \\
\hline Europe/Central Asia & $\begin{array}{l}0.275 \\
(0.292)\end{array}$ & $\begin{array}{l}0.284 \\
(0.298)\end{array}$ & $\begin{array}{l}0.296 \\
(0.293)\end{array}$ & $\begin{array}{l}0.318 \\
(0.294)\end{array}$ \\
\hline war months & $\begin{array}{l}-0.011 \\
(0.005)^{* *}\end{array}$ & $\begin{array}{l}-0.012 \\
(0.005)^{* *}\end{array}$ & $\begin{array}{l}-0.012 \\
(0.005)^{* *}\end{array}$ & $\begin{array}{l}-0.013 \\
(0.005)^{* *}\end{array}$ \\
\hline peace-onset & & $\begin{array}{l}0.287 \\
(0.438)\end{array}$ & & \\
\hline post-conflict 1 & & & $\begin{array}{l}-0.407 \\
(0.607)\end{array}$ & \\
\hline post-conflict 2 & & & & $\begin{array}{l}-1.058 \\
(0.376)^{* * *}\end{array}$ \\
\hline $\begin{array}{l}\text { Observations } \\
\text { Post-conflict observations }\end{array}$ & 354 & $\begin{array}{l}354 \\
14\end{array}$ & $\begin{array}{l}354 \\
13\end{array}$ & 354 \\
\hline $\mathrm{R}^{2}$ & 0.63 & 0.63 & 0.63 & 0.63 \\
\hline
\end{tabular}

Note: Dependent Variable: ODA/GDP. Robust standard errors in parentheses. * significant at 10\%; ** significant at $5 \% ;{ }^{* * *}$ significant at $1 \%$. All regressions include time dummies which are jointly significant. 
Table 5: Means of Policy and Governance Variables

\begin{tabular}{l|lllll}
\hline & all countries & \multicolumn{5}{c}{ post-conflict countries } \\
\hline & & Period 1 & Period 2 & Period 3 & All \\
& & & & & Periods \\
Policy (CPIA) & 3.00 & 2.41 & 2.88 & 3.05 & 2.67 \\
Macro policy $^{\text {Structural policy }}{ }^{1}$ & 1.03 & 1.05 & 1.02 & 1.08 & 1.04 \\
Social policy $^{1}$ & 0.99 & 0.98 & 1.01 & 0.94 & 0.98 \\
Governance (ICRGE) & 0.97 & 0.97 & 0.98 & 0.98 & 0.98 \\
\hline
\end{tabular}

${ }^{1}$ Relative to the average of macro, structural and social policies. 
Table 6: Policy Priorities

\begin{tabular}{|c|c|c|}
\hline & (1) & (2) \\
\hline Initial per capita income & $\begin{array}{l}0.747 \\
(0.622)\end{array}$ & $\begin{array}{l}0.657 \\
(0.651)\end{array}$ \\
\hline Governance (ICRGE) & $\begin{array}{l}0.225 \\
(0.162)\end{array}$ & $\begin{array}{l}0.270 \\
(0.159)^{*}\end{array}$ \\
\hline CPIA & $\begin{array}{l}0.962 \\
(0.396)^{* *}\end{array}$ & $\begin{array}{l}1.034 \\
(0.401)^{* *}\end{array}$ \\
\hline ODA/GDP x CPIA & $\begin{array}{l}0.157 \\
(0.065)^{* *}\end{array}$ & $\begin{array}{l}0.143 \\
(0.063)^{* *}\end{array}$ \\
\hline$(\mathrm{ODA} / \mathrm{GDP})^{2}$ & $\begin{array}{l}-0.031 \\
(0.013)^{* *}\end{array}$ & $\begin{array}{l}-0.029 \\
(0.012)^{* *}\end{array}$ \\
\hline post-conflict $0-2$ & $\begin{array}{l}0.738 \\
(2.813)\end{array}$ & $\begin{array}{l}0.644 \\
(0.855)\end{array}$ \\
\hline post-conflict $0-2 \times$ Governance & $\begin{array}{l}0.109 \\
(0.676)\end{array}$ & \\
\hline South Asia & $\begin{array}{l}2.465 \\
(0.624)^{* * *}\end{array}$ & $\begin{array}{l}2.542 \\
(0.670)^{* * *}\end{array}$ \\
\hline East Asia & $\begin{array}{l}2.824 \\
(0.661)^{* * *}\end{array}$ & $\begin{array}{l}2.623 \\
(0.683)^{* * *}\end{array}$ \\
\hline Sub-Saharan Africa & $\begin{array}{l}-0.608 \\
(0.811)\end{array}$ & $\begin{array}{l}-0.595 \\
(0.845)\end{array}$ \\
\hline Middle East/ North Africa & $\begin{array}{l}1.502 \\
(0.562)^{* * *}\end{array}$ & $\begin{array}{l}1.384 \\
(0.542)^{* *}\end{array}$ \\
\hline Europe/Central Asia & $\begin{array}{l}-0.431 \\
(1.048)\end{array}$ & $\begin{array}{l}-0.266 \\
(1.060)\end{array}$ \\
\hline Macro Policy & & $\begin{array}{l}5.038 \\
(3.711)\end{array}$ \\
\hline Social Policy & & $\begin{array}{l}0.282 \\
(3.671)\end{array}$ \\
\hline Postconflict 0-2 x Macro Policy & & $\begin{array}{l}-13.162 \\
(3.582)^{* * *}\end{array}$ \\
\hline Postconflict 0-2 x Social Policy & & $\begin{array}{l}16.167 \\
(3.778)^{* * *}\end{array}$ \\
\hline $\begin{array}{l}\text { Observations } \\
\text { Post-conflict observations }\end{array}$ & $\begin{array}{l}344 \\
34\end{array}$ & $\begin{array}{l}341 \\
34\end{array}$ \\
\hline $\mathrm{R}^{2}$ & 0.37 & 0.39 \\
\hline
\end{tabular}

Note: Robust standard errors in parentheses. * significant at $10 \%$; ** significant at $5 \%$; ${ }^{* * *}$ significant at $1 \%$. All regressions include time dummies which are jointly significant. 


\section{Appendix}

\section{Sample:}

The core sample contains 349 observations from the following 62 countries:

Algeria, Argentina, Bahamas, Bangladesh, Bolivia, Botswana, Brazil, Cameroon, Chile, Colombia, The Democratic Republic of the Congo, Costa Rica, Cote d'Ivoire, Dominican Republic, Ecuador, Egypt, El Salvador, Ethiopia, Gabon, Gambia, Ghana, Guatemala, Guyana, Haiti, Honduras, Hungary, India, Indonesia, Jamaica, Kenya, South Korea, Madagascar, Malawi, Malaysia, Mali, Mexico, Morocco, Nicaragua, Niger, Nigeria, Pakistan, Panama, Paraguay, Peru, Philippines, Senegal, Sierra Leone, Singapore, South Africa, Sri Lanka, Sudan, Syria, Tanzania, Thailand, Togo, Trinidad and Tobago, Tunisia, Turkey, Uruguay, Venezuela, Zambia and Zimbabwe.

\section{Variable Definitions:}

We use information from two data sets for this paper. The economic and policy data was taken from Collier and Dollar (2001) and the conflict data is based on the Collier and Hoeffler (2002a) data set. We list all civil wars in Table A1.

The Collier and Dollar data set is a panel, spanning 12 four year periods (1966-69, 1970 $73, \ldots, 1994-98)$ for 199 countries, thus it contains 2388 potential observations. In their analysis Collier and Dollar use data for the six most recent periods (1974-77, ..., 199497). Due to missing data their sample size is 349 observations.

\section{Growth}

The average annual growth rate of per capita GDP. Source: Collier and Dollar (2001).

\section{Initial per capita income}

Per capita income measured at the beginning of each sub-period $(1974,1978, \ldots, 1994)$. Data are in 1990 constant US dollars. Source: Collier and Dollar (2001).

\section{Policy}

The Policy measure used is the World Bank's Country Policy and Institutional Assessment (CPIA). It ranges from 1 (poor) to 5 (good). The CPIA measure of policy has 20 equally weighted components divided into four categories as follows:

\section{A. Macroeconomic Management and Sustainability of Reforms}

1. General Macroeconomic Performance

2. Fiscal Policy

3. Management of External Debt

4. Macroeconomic Management Capacity

5. Sustainability of Structural Reforms 
B. Structural Policies for Sustainable and Equitable Growth

$\begin{array}{ll}\text { 1. } & \text { Trade Policy } \\ \text { 2. } & \text { Foreign Exchange Regime } \\ \text { 3. } & \text { Financial Stability and Depth } \\ \text { 4. } & \text { Banking Sector Efficiency and Resource Mobilization } \\ \text { 5. } & \text { Property Rights and Rule-based Governance } \\ \text { 6. } & \text { Competitive Environment for the Private Sector } \\ \text { 7. } & \text { Factor and Product Markets } \\ \text { 8. } & \text { Environmental Policies and Regulations }\end{array}$

C. Policies for Social Inclusion

1. Poverty Monitoring and Analysis

2. Pro-poor Targeting and Programs

3. Safety Nets

D. Public Sector Management

1. Quality of Budget and Public Investment Process

2. Efficiency and Equity of Revenue Mobilization

3. Efficiency and Equity of Public Expenditures

4. Accountability of the Public Service

\section{Governance}

We measure governance with the International Country Risk Guide (ICRG) data, it is a composite index and ranges from 1 (poor) to 6 (good). Source: Collier and Dollar (2002).

Overseas Development Assistance

Overseas Development Assistance (ODA) is measured as a percentage of GDP. Source: Collier and Dollar (2002).

\section{Post-conflict}

Is a dummy variable, taking the value of one for the three periods after the war ended, i.e. if the war ended in 1975 the dummy takes the value one for the following periods: 197477, 1978-1981 and 1982-85.

\section{Post-conflict 0}

Is a dummy variable, taking the value one for the period in which the war ended, i.e. if the war ended in 1975 the dummy takes the value one for the period: 1974-77.

\section{Post-conflict 1}

Is a dummy variable, taking the value one for the period after the war ended, i.e. if the war ended in 1975 the dummy takes the value one for the 1978-1981 period. 


\section{Post-conflict 2}

Is a dummy variable, taking a value of one for the second period after the war ended, i.e. if the war ended in 1975 the dummy takes the value one for the 1982-1985 period.

\section{Warmonths}

Is the sum of months at war during the period.

\section{Peace-onset}

Is the number of months after the conflict end. We only consider the immediate post conflict period. For example if the war ended in June 1975 this variable takes a value of 18 for period $1974-77$ and zero for all other periods.

\section{Post-conflict Year}

Post-conflict year indicates how many post-conflict years there are in each sub-period. We measure the number of months in the period that fall into the following category: first 12 months post-conflict, second 12 months post-conflict etc. We consider the first eight years since the end of the conflict. As an example take a war that ended in June 1976:

for period 1974-77 $\mathrm{yr} 1=6, \mathrm{yr} 2=12, \mathrm{yr} 3=0 \ldots \mathrm{yr} 8=0$

for period 1978-81 yrl $=0, \mathrm{yr} 2=0, \mathrm{yr} 3=12, \mathrm{yr} 4=12, \mathrm{yr} 5=12, \mathrm{yr} 6=12, \mathrm{yr} 7=0, \mathrm{yr} 8=0$ for period $1982-85$ yr $1=0 \ldots y \mathrm{yr} 6=0, \mathrm{yr} 7=12, \mathrm{yr} 8=12$

$1^{\text {st }}-3^{\text {rd }}$ Post-conflict year

Is a dummy variable which takes the value of one if either post-conflict year variables for years $1-3$ are positive.

\section{$4^{\text {th }}-7^{\text {th }}$ Post-conflict year}

Is a dummy variable which takes the value of one if either post-conflict year variables for years $4-7$ are positive. 


\section{Table A1: Civil Wars}

\begin{tabular}{|c|c|c|c|c|c|}
\hline Country & $\begin{array}{l}\text { Start of the } \\
\text { War }\end{array}$ & $\begin{array}{l}\text { End of the } \\
\text { War }\end{array}$ & peace-onset & postconflict 1 & postconflict 2 \\
\hline Angola & $11 / 75$ & $05 / 91$ & & & \\
\hline Burundi & $04 / 72$ & $12 / 73$ & & $*$ & \\
\hline Burundi & $08 / 88$ & $08 / 88$ & & $*$ & \\
\hline Chad & $03 / 80$ & 08/88 & & $*$ & $*$ \\
\hline Congo & 97 & $10 / 97$ & & & \\
\hline El Salvador & $10 / 79$ & $01 / 92$ & $*$ & $* *$ & \\
\hline Ethiopia & $07 / 74$ & $05 / 91$ & $*$ & $* *$ & \\
\hline Guatemala & $07 / 66$ & $07 / 72$ & & $* *$ & \\
\hline Guatemala & $03 / 78$ & $03 / 84$ & $*$ & $*$ & ** \\
\hline Guinea-Bissau & $12 / 62$ & $12 / 74$ & & $* *$ & * \\
\hline India & 84 & 94 & $*$ & & \\
\hline Indonesia & $06 / 75$ & $09 / 82$ & * & ** & $* *$ \\
\hline Iran & $06 / 81$ & $05 / 82$ & & & $*$ \\
\hline Jordan & $09 / 70$ & $09 / 70$ & & * & * \\
\hline Morocco & $10 / 75$ & $11 / 89$ & * & ** & $* *$ \\
\hline Mozambique & $07 / 76$ & $10 / 92$ & & $*$ & \\
\hline Nicaragua & $10 / 78$ & $07 / 79$ & $*$ & & \\
\hline Nicaragua & $03 / 82$ & $04 / 90$ & $*$ & $* *$ & \\
\hline Nigeria & $01 / 66$ & $01 / 70$ & & $* *$ & \\
\hline Nigeria & $12 / 80$ & $08 / 84$ & * & ** & $* *$ \\
\hline Pakistan & $01 / 73$ & $07 / 77$ & $*$ & $* *$ & $* *$ \\
\hline Peru & $03 / 82$ & $12 / 96$ & * & & \\
\hline Philippines & $09 / 72$ & $12 / 96$ & $*$ & & \\
\hline Romania & $12 / 89$ & $12 / 89$ & & $*$ & \\
\hline Russia & $12 / 94$ & $08 / 96$ & & & \\
\hline Rwanda & $10 / 90$ & $07 / 94$ & & & \\
\hline Somalia & $05 / 88$ & $12 / 92$ & $* *$ & & \\
\hline Sri Lanka & $04 / 71$ & $05 / 71$ & & ** & $* *$ \\
\hline Sudan & $10 / 63$ & $02 / 72$ & & ** & $* *$ \\
\hline Uganda & $10 / 80$ & $04 / 88$ & & $*$ & * \\
\hline Zimbabwe & $12 / 72$ & $12 / 79$ & $*$ & ** & ** \\
\hline
\end{tabular}

Cols 2\&4: two stars indicate that the post-conflict observations are included in the 344 sample, one star indicates that the observation was also included in the 532 sample. 





\section{Policy Research Working Paper Series}

Title

WPS2881 Returns to Investment in Education: A Further Update

WPS2882 Politically Optimal Tariffs: An Application to Egypt

WPS2883 Assessing the Distributional Impact of Public Policy

WPS2884 Privatization and Labor Force Restructuring around the World

WPS2885 Poverty, AIDS, and Children's Schooling: A Targeting Dilemma

WPS2886 Examining the Feasibility of Livestock Insurance in Mongolia

WPS2887 The Demand for Commodity Insurance by Developing Country Agricultural Producers: Theory and an Application to Cocoa in Ghana

WPS2888 A Poverty Analysis Macroeconomic Simulator (PAMS) Linking Household Surveys with Macro-Models

WPS2889 Environmental Performance Rating and Disclosure: China's GreenWatch Program

WPS2890 Sector Organization, Governance, and the Inefficiency of African Water Utilities

WPS2890 Sector Organization, Governance, and the Inefficiency of African Water Utilities

WPS2891 Trends in the Education Sector from 1993-98

WPS2892 Productivity or Endowments? Sectoral Evidence for Hong Kong's Aggregate Growth

WPS2893 Banking on Foreigners: The Behavior of International Bank Lending to Latin America, 1985-2000

WPS2894 Telecommunications Sector Reforms in Senegal
Author

George Psacharopoulos Harry Anthony Patrinos

Dorsati Madani

Marcelo Olarreaga

B. Essama-Nssah

Alberto Chong

Florencio Lopez-de-Silanes

Martha Ainsworth

Deon Filmer

Jerry R. Skees

Ayurzana Enkh-Amgalan

Alexander Sarris

Luiz A. Pereira da Silva

B. Essama-Nssah

Issouf Samaké

Hua Wang

Jun Bi

David Wheeler

Jinnan Wang

Dong Cao

Genfa Lu

Yuan Wang

Antonio Estache

Eugene Kouassi

Antonio Estache

Eugene Kouassi

Nga Nguyet Nguyen

Hiau Looi Kee

Maria Soledad Martinez Peria

Andrew Powell

Ivanna Vladkova Hollar

Jean-Paul Azam

Magueye Dia

Tchétché N'Guessan
Date

Contact

for paper

September 2002

N. Vergara

30432

September $2002 \quad$ P. Flewitt

32724

September $2002 \quad$ O. Kootzemew

35075

September $2002 \quad H$. Sladovich

37698

September $2002 \quad H$. Sladovich

37698

September $2002 \quad$ E. Laguidao

82450

September 2002 M. Fernandez 33766

September $2002 \quad$ R. Yazigi

September $2002 \quad$ Y. D'Souza 31449

September 2002

G. Chenet-Smith 36370

September 2002 G. Chenet-Smith 36370

September $2002 \quad$ E. Khine 37471

September $2002 \quad$ P. Flewitt 32724

September 2002

A. Yaptenco 31823

September 2002 P. Sintim-Aboagye 38526 


\section{Policy Research Working Paper Series}

Title

WPS2895 Telecommunications Reform in Côte d'Ivoire

WPS2896 The Wage Labor Market and Inequality in Vietnam in the 1990s

WPS2897 Gender Dimensions of Child Labor and Street Children in Brazil

WPS2898 Relative Returns to Policy Reform: Evidence from Controlled CrossCountry Regressions

WPS2899 The Political Economy of Fiscal Policy and Economic Management in Oil-Exporting Countries

WPS2900 Economic Structure, Productivity, and Infrastructure Quality in Southern Mexico

WPS2901 Decentralized Creditor-Led Corporate Restructuring: CrossCountry Experience
Author

Date

Jean-Jacques Laffont

Tchétché N'Guessan

John Luke Gallup

Emily Gustafsson-Wright Hnin Hnin Pyne

Alexandre Samy de Castro October 2002 Ian Goldin

Luiz A. Pereira da Silva

Benn Eifert

Alan Gelb

Nils Borje Tallroth

Uwe Deichmann

Marianne Fay

Jun Koo

Somik V. Lall

Marinela E. Dado

Daniela Klingebiel

October 2002

October 2002

October 2002
Contact for paper

September 2002

P. Sintim-Aboagye 38526

September 2002

E. Khine 37471

M. Correia 39394

R. Yazigi 37176

J. Schwartz 32250

Y. D'Souza 31449

R. Vo

33722 